Bangladesh J. Zool. 48(2): 399-411, 2020

ISSN: 0304-9027

eISSN: 2408-8455

\title{
DIAGNOSIS OF THREE PUMKIN LEAF BEETLE (AULACOPHORA SPP.: CHRYSOMELIDAE; COLEOPTERA) PESTS THROUGH MOLECULAR mTDNA-COI BARCODE APPROACH
}

\author{
Sumita Rani Das, Jannatul Ferdous Tithi, Susmita Sarker, Faria Farhana Rain \\ and Abu Faiz Md. Aslam* \\ Molecular Entomology Laboratory, Department of Zoology, Jahangirnagar \\ University, Savar, Dhaka, Bangladesh
}

\begin{abstract}
Pest management relies on proper identification of insect species, which usually depends on morphological keys. In this research, DNA barcoding was used to identify three pest species of genus Aulacophora (A. foveicollis, A. lewisii and $A$. indica) attacking horticultural crops in Bangladesh. Accurate phylogenetic information and evolutionary divergence data were supported and evidenced by various parameters, including the rates of substitution, nucleotide composition and genetic divergence. The nucleotide composition of these three species indicates that the total adenine and thiamine content $(\mathrm{A}+\mathrm{T}, 67.3 \%)$ was higher than the guanine and cytosine content $(\mathrm{G}+\mathrm{C}, 32.87 \%)$. Intraspecific genetic divergence ranged from 0.0158-0.1415. To confirm the origin and evolution, phylogenetic tree and haplotype network was drawn. Both the maximum likelihood and neighbor joining analyses showed that A. indica and A. foveicollis were clustered in one group, and $A$. lewisii was originated from another group. Haplotype showed that $A$. lewisii has the highest amount of mutational steps among the sequenced pests and genetically distant species from its common ancestors by 78 mutational numbers. Present investigation can be reliably treated for developing reference libraries for species identification via sequence matches and designing specific pest management approach.

Key words: Aulacophora, COI gene, phylogenetic analysis, genetic distance,
\end{abstract} haplotype network.

\section{INTRODUCTION}

The genus Aulacophora (Coleoptera: Chrysomelidae) are mostly known as plant pests which attack a wide variety of mono and dicotyledonous families. Many species of this genus are severe pests of economic value which cause damage by feeding and transmit viruses (Aslan et al. 2000, Gillespie et al. 2008). In Bangladesh, the pumpkin beetle or cucurbit beetle namely Aulacophora foveicollis, A. lewisii and A. indica are the major pests of cucurbitaceous

\footnotetext{
*Author for corresponding: <afmaslam@juniv.edu>;

○2020 Zoological Society of Bangladesh DOI: https://doi.org/10.3329/bjz.v48i2.52379
} 
vegetables (Reeta and Johri 2003). These beetles attack more than 81 plant species specially cucumber, white gourd, sweet gourd, bottle gourd, watermelon and muskmelon which may reach upto 35-100\% (Butani and Jotwani 1984, Kamal et al. 2014, Rashid et al. 2014). Both the adults and the grubs of these beetles cause considerable damage to cucurbits during all stages of plant growth. Adults feed on the leaves, flowers and in some cases on fruits, while the grubs attack the roots, underground stem and leaves closely in touch with soil, thereby lowering the yield substantially (Uddin 1996, Begum 2002, Hassan et al. 2012). The beetles also injure fruit producing characteristic circular bands of injury which help in rotting and subsequent attack of diseases of the fruits (Azim 1966).

Accurate taxonomic identification is the pivotal issue in biological research in order to allow the implementation of adequate measures to contend with species of medical or agricultural importance (Miller and Rossman 1995). Identification based on morphology has some limitation, for instance it is difficult even for specialist to accurately identify female and immature stages which is extremely important for pest management (Wallman and Donnellan 2001). In addition to morphological keys, molecular markers specifically DNA based molecular markers are widely being used to resolve the systematic issues in different organisms including coleopteran pests (Mukha et al. 2001, Pechal et al. 2008, Hashemi-Aghdam et al. 2017).

Mitochondrial (Mt) DNA has been used as molecular markers for phylogenetic studies in animals because of its simple genome structure. The commonly adopted standard 658bp COI segment has proven to be highly informative and useful for species level identification (Yang and Rannala 2010, Bergsten et al. 2012). The DNA barcoding of any pests may be challenging but is extremely worthwhile, as it possibly reflects several evolutionary processes. The present study aims to conduct molecular characterization of three Aulacophora pests based on Mt DNA barcode of COI gene. This information will help the researchers to know the efficiency of the barcoding of pest species and indicate a guideline for future research. The overall goal is to avail tools that will contribute timely and accurate identification of these pests from any life stage which would in turn facilitate quicker and effective implementation of pest management system in areas affected by this pest.

\section{MATERIAL AND METHODS}

Sample collection and genomic DNA extraction: The pest specimens (Fig. 1) were collected with the help of sweeping net from various regions of Bangladesh. Somatic tissue rich in mitochondria (e.g., leg or elytra) were separated carefully 
from the specimens, cleaned by ethanol and kept for molecular analysis. The rest of the body of each sample was stored in $-20^{\circ} \mathrm{C}$ freezer as a voucher specimen.

The genomic DNA was extracted from leg or wing tissue using Wizard ${ }^{\circledR}$ Genomic DNA Purification Kit, USA, following the manufacturer's protocol after slight modification as mentioned in Aslam et al. 2019a and 2019b. The yield of extracted DNA was measured using NanoDrop ${ }^{\mathrm{TM}} 2000$ spectrophotometer (Thermo Fisher Scientific, USA).
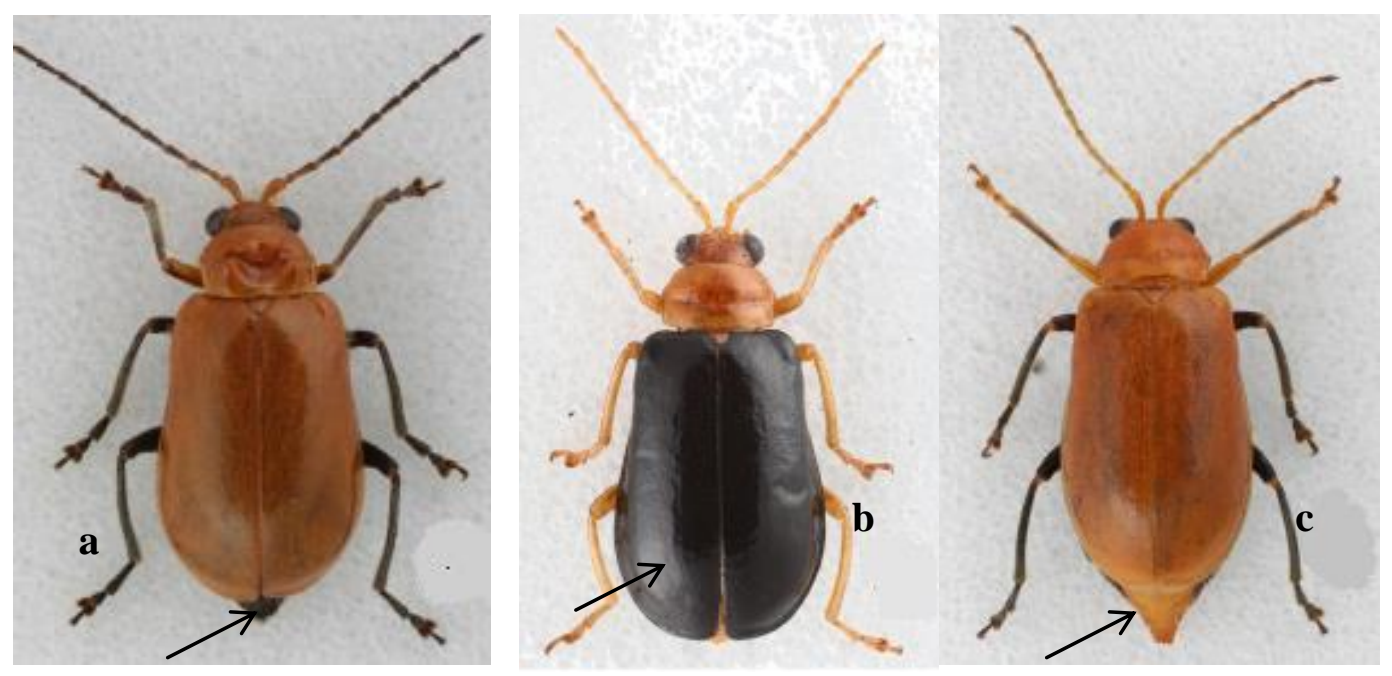

Fig.1. Photographic representation of a. A. foveicollis (blackish pygidium), b. A. lewisii (black elytra) and c. A. indica (yellowish brown pygidium)

PCR amplification and gel documentation: The genomic DNA extracts were subjected to PCR amplification of a $658 \mathrm{bp}$ region near the $5^{\prime}$ terminus of the CO1 gene following standard protocols. Primers used were forward primer: (LCO 1490 5'-GGTCAACAAATCATAAAGATATTG G-3') and reverse primer: (HCO 2198 5'-TAAACTTCAGGGTGACCAAAAAATCA-3') (Folmer et al. 1994). PCR reactions were carried out with $20 \mu 1$ reaction volume containing Promega Gotaq ${ }^{\circledR}$ G2 Green Master Mix $10 \mu \mathrm{l}$, (that contained DNA Polymerase, dNTPs, $\mathrm{MgCl}_{2}$ and reaction buffers); forward and reverse primers - $1 \mu \mathrm{l}$ each (10 pmol/ $\mu \mathrm{l})$; template DNA and nuclease free water (adjustable). Thermo cycling consisted of an initial denaturation of $94{ }^{\circ} \mathrm{C}$ for $3 \mathrm{~min}$, followed by 30 cycles of denaturation at $94^{\circ} \mathrm{C}$ for $30 \mathrm{sec}$, annealing at $49^{\circ} \mathrm{C}$ for $30 \mathrm{sec}$, extension at $72{ }^{\circ} \mathrm{C}$ for $1 \mathrm{~min}$, final extension: $72^{\circ} \mathrm{C}$ for $10 \mathrm{~min}$ and hold: $4^{\circ} \mathrm{C}$. PCR was performed using a Veriti ${ }^{\circledR}$ Thermal Cycler from Thermo Fisher Scientific, USA. The amplified product 
was analyzed on a 1.5\% agarose gel electrophoresis. The DNA was then visualized under gel documentation system - BioDoc Analyzer of Biometra, Germany.

DNA sequencing and Bioinformatic analysis: The PCR products were purified using Promega Wizard ${ }^{\circledR}$ SV Gel and PCR clean up system manufactured by Promega Corporation, USA. The quantity and purity of PCR purified products was measured by using NanoDrop 2000 spectrophotometer. Big Dye ${ }^{\circledR}$ Terminator v3.1 cycle sequencing kit was used to sequence the desired region of gene. Each species was bi-directionally sequenced to get sequence of both (5' and $3^{\prime}$ ) the DNA strands. After proper editing of the gene using FinchTV software all the sequences were deposited in the NCBI GenBank (BankIt) to obtain accession numbers.

COI sequences were aligned using ClustalW algorithm with the help of MEGA $\mathrm{X}$. Multiple sequence alignment images were prepared using Jalview, version 2.8. Nucleotide frequencies and genetic distances among sequences were calculated using Kimura's two parameter model (K2P) of base substitution in MEGA X (Kumar et al. 2018). Haplotypes were constructed using the program Pop art 1.7 based on TCS network (Clement et al. 2000). Phylogenetic trees were reconstructed using two different reconstruction methods, maximum likelihood (ML) and neighbor joining (NJ) based on MEGA X software. The percentage of replicate trees in which the associated taxa clustered together in the bootstrap test (1000 replicates) are shown next to the branches.

\section{RESULTS AND DISCUSSION}

Species of Aulacophora caused taxonomic confusion because of their same size and color and same host plants. Among three studied species, A. lewisii was separated from $A$. foveicollis and A. indica by their shiny black elytra (Fig. 1). Both the $A$. foveicollis and $A$. indica had reddish brown color elytra and distinguished from one another by their pygidium color (Fig. 1). The pygidium was blackish in A. foveicollis and yellowish brown in A. indica (Lee and Beenen 2015). For accurate identification, COI gene of Aulacophora species were sequenced. The desired PCR amplified COI gene was visualized under gel documentation system. All the samples showed (Figure not shown) single and desired band between 500-700bp which indicated confirmation of desired gene amplification.

Sequence result and BLAST analysis: The Mt-COI barcode region from four samples were sequenced and BLAST (Basic Local Alignment Search Tool) was used to check sequence identity between the retrieved sequences and GenBank 
library or database of sequences from NCBI GenBank. A total of four samples were sequenced that belonged to three species (A. foveicollis, A. lewisii and A. indica). Obtained GenBank accession numbers for Aulacophora foveicollis, A. lewisii, A. indica (1) and A. indica (2) are MH423247.1, MG587922.1, MK029357.1 and MH748452.1 respectively. BLAST analysis result (Table 1) revealed that all the obtained sequences shared 99\% similarity with gene from GenBank. Results indicated that species could be differentiated by COI barcoding.

Table 1. BLAST analysis results of sequenced Aulacophora pests

\begin{tabular}{lllll}
\hline \multicolumn{1}{c}{ Species } & A. foveicollis & A. lewisii & A. indica (1) & A. indica (2) \\
\hline BLAST & KP898252.1 & KC185696.1 & KC845871.1 & KY836017.1 \\
Accession No. & & & & \\
Homology & $99 \%$ & $99 \%$ & $99 \%$ & $99 \%$ \\
Query cover & $100 \%$ & $100 \%$ & $84 \%$ & $85 \%$ \\
Total score & 1186 & 1206 & 1027 & 1016 \\
E value & 0.0 & 0.0 & 0.0 & 0.0 \\
\hline
\end{tabular}

Alignment of COI sequence: The alignment of COI gene was performed among 3 Aulacophora pest species (Fig. 2). Non-conserved regions (110) were presented by letter and identical or conserved regions (560) were indicated by dot (Fig. 2). All the species showed $83.58 \%$ similarity among them.

Nucleotide base contents: Retrieved sequences were subjected to analysis of nucleotide composition which showed percentage of base contents in COI region. Total nucleotide base composition of the COI fragment varied among the specimens with an expected AT bias (Table 2). The total adenine and thiamine content $(\mathrm{A}+\mathrm{T}, 67.3 \%)$ was higher than the guanine and cytosine content $(\mathrm{G}+\mathrm{C}$, $32.87 \%)$. The average largest number of nucleotide was thiamine ( $\mathrm{T}, 38.2 \%)$ and lowest was guanine (C, 16.1\%).

Genetic distance analysis: Genetic distance denotes the mutation among individuals which are shown in the Table 3 . Codon positions included were $1 \mathrm{st}+2 \mathrm{nd}+3 \mathrm{rd}+$ Noncoding. There were a total of 643 nucleotide base in the final dataset. Intraspecific genetic divergence ranged from 0.0158-0.1415 (Table 3). The lowest genetic distance (0.0158) was found between A. foveicollis and $A$. indica (1) and the highest genetic distance $(0.1415)$ was found between $A$. foveicollis and A. lewisii. 


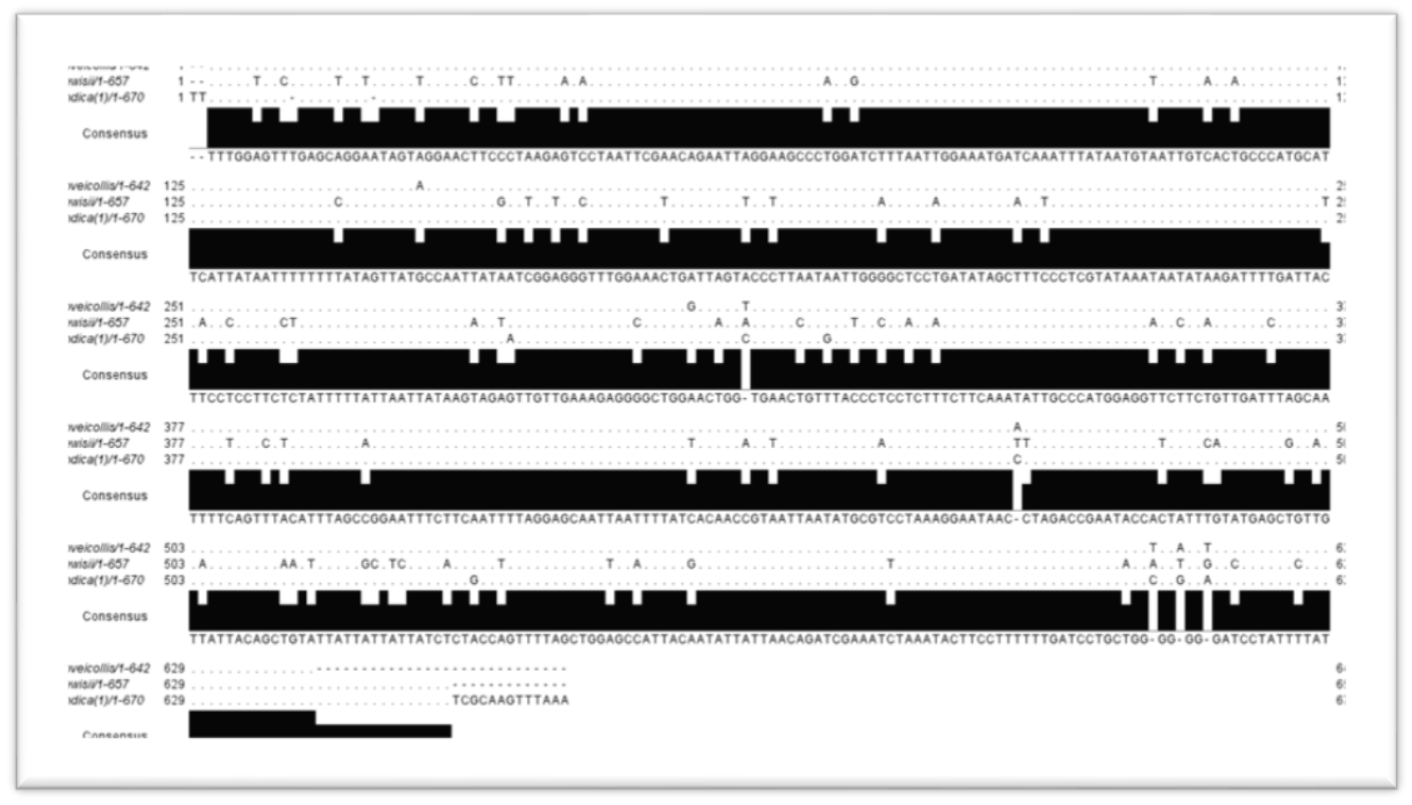

Fig. 2. Multiple sequence alignment based on COI gene, the dots indicate the conserved and the base pairs indicate the non- conserved region.

Table 2. Nucleotide base contents in three Aulacophora pests

\begin{tabular}{lcccccc}
\hline \multicolumn{1}{c}{ Species name } & $\mathbf{T}(\mathbf{U}) \%$ & $\mathbf{C \%}$ & $\mathbf{A \%}$ & $\mathbf{G \%}$ & $\mathbf{( A + T ) \%}$ & $\mathbf{( G + C ) \%}$ \\
\hline Aulacophora foveicollis & 38.3 & 16.3 & 28.8 & 16.6 & 67.1 & 32.9 \\
Aulacophora lewisii & 38.0 & 15.8 & 29.6 & 16.6 & 67.6 & 32.4 \\
Aulacophora indica (1) & 38.3 & 16.1 & 28.4 & 17.2 & 67.1 & 33.3 \\
Average & 38.2 & 16.1 & 28.9 & 16.8 & 67.3 & 32.87 \\
\hline
\end{tabular}

Table 3. Intraspecific K2P divergence at the COI gene region among three Aulacophora species

\begin{tabular}{lccc}
\hline \multicolumn{1}{c}{ Species name } & $\mathbf{1}$ & $\mathbf{2}$ & $\mathbf{3}$ \\
\hline Aulacophora foveicollis & - & & \\
Aulacophora lewisii & 0.1415 & - & \\
Aulacophora indica (1) & 0.0158 & 0.1406 & - \\
\hline
\end{tabular}

Phylogenetic tree analysis: Both the maximum likelihood and neighbor joining tree were constructed to realize the phylogenetic relationship using four sequences (marked with Bangladesh*) and other sequences of Aulacophora species from different country available in the NCBI GenBank were used for a proper comparison among the Coleopteran pests. Fig. 3 and Fig. 4 indicated that A. indica (1), A. indica (2), A. foveicollis were clustered in one group while A. lewisii was in another group. A. indica (1), A. indica (2) and A. foveicollis also 
formed sub-branched with identical species from different country. In maximum likelihood tree, A. foveicollis showed highest $92 \%$ similarity with another $A$. foveicollis species having accession KP898252.1 and KU557524.1 from India. The bar at the bottom provides a scale for the genetic distance.

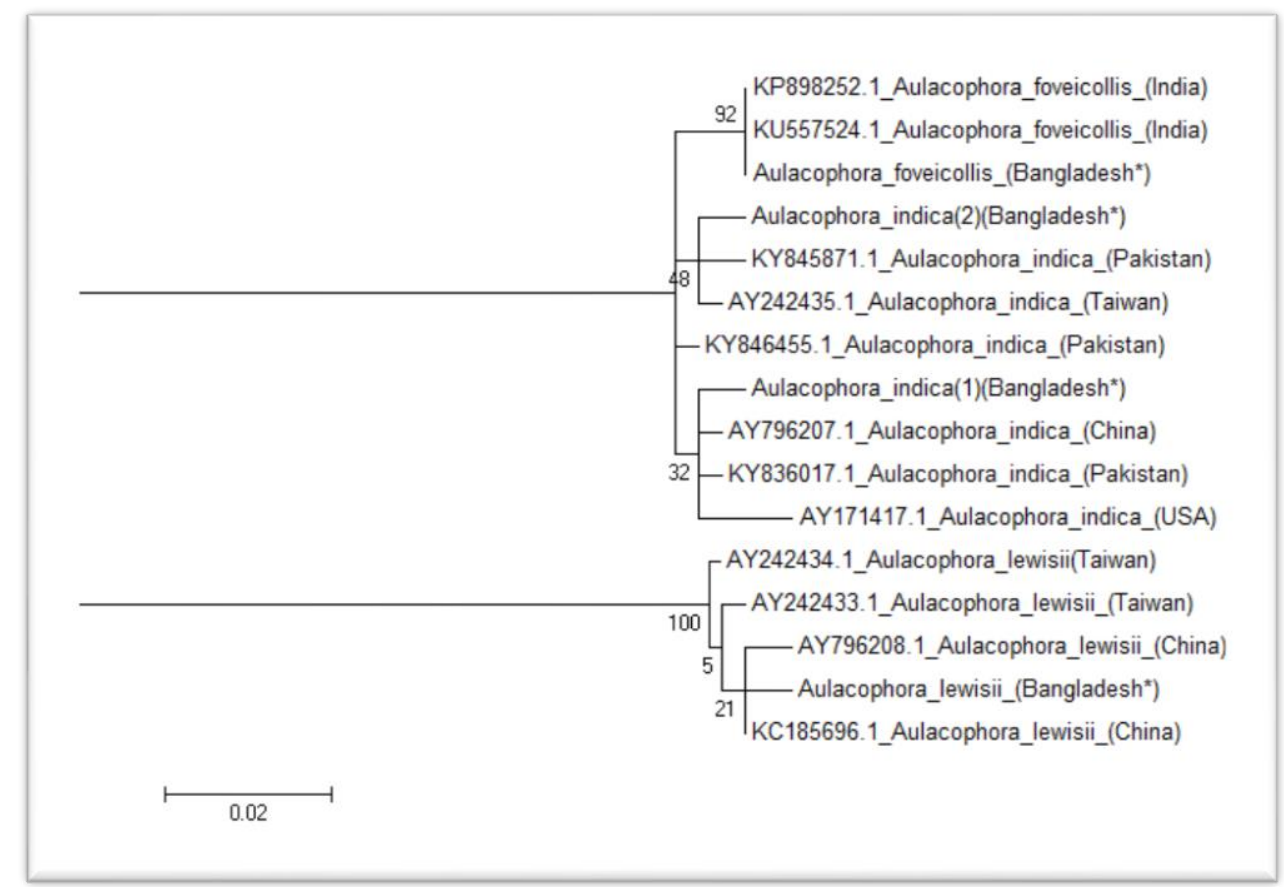

Fig. 3. The evolutionary history was inferred by using the Maximum Likelihood method based on the Kimura 2-parameter model. The tree with the highest log likelihood (-864.3941) is shown. The analysis involved 16 nucleotide sequences. Codon positions included were $1 \mathrm{st}+2 \mathrm{nd}+3 \mathrm{rd}+$ Noncoding. All positions containing gaps and missing data were eliminated.

Relative synonymous codon use: From the table 4 it was revealed that highest number of codon usage frequency is 4.21 and obtained from the codon UUA and the lowest codon frequency 0 found in codon CUC, UCG, CCG, UAG, CAG, AAG, GAG, UGU, UGC, UGG, CGC, CGG and AGG that means they were not active.

Haplotype: Statistical parsimony (TCS) haplotype network (Fig. 5) was constructed based on COI gene sequences of coleopteran pests. Haplotype network analysis with mitochondrial COI gene of three Aulacophora pests showed high genetic diversity among them. A. indica (1), A. indica (2) and A. foveicollis were separated from an immediate common ancestor by 5,4 and 5 mutational steps, respectively. Again, A. lewisii was separated by 78 mutational 


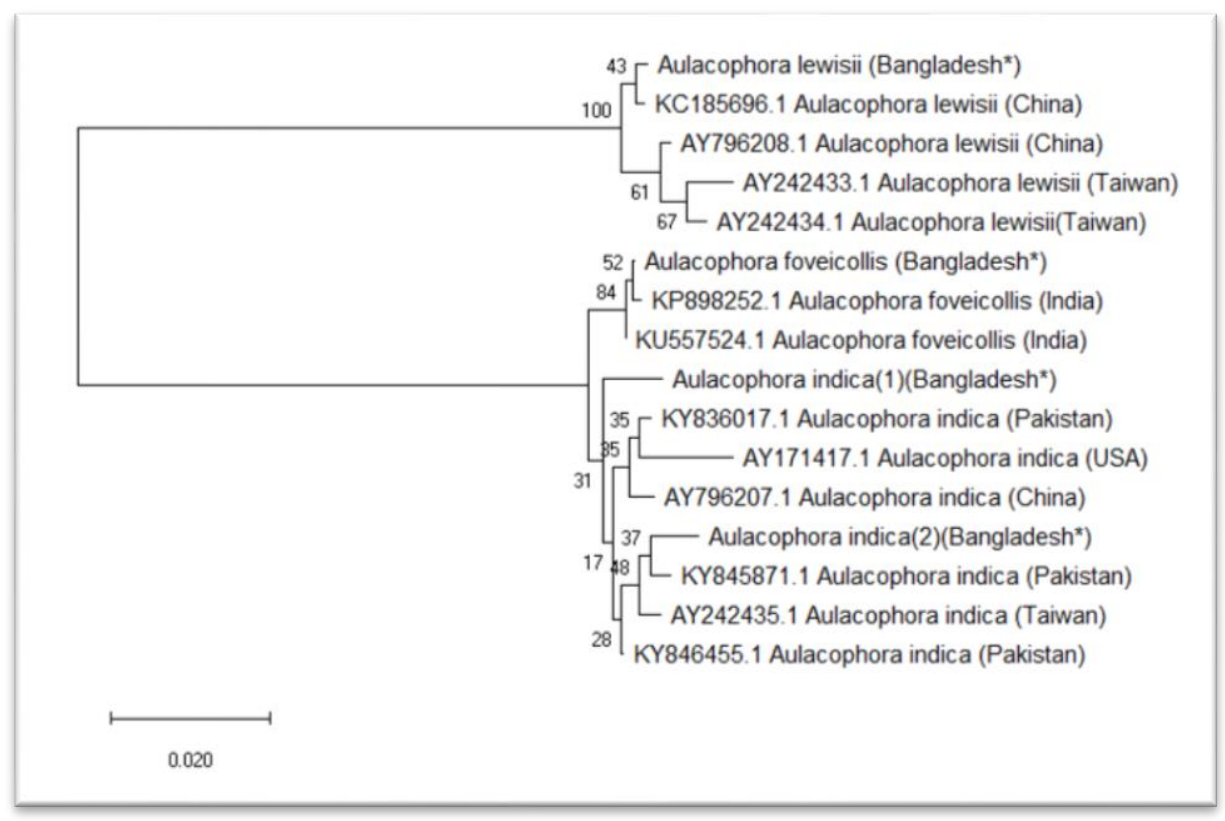

Fig. 4. The evolutionary history was inferred using the Neighbor-Joining method. The optimal tree with the sum of branch length $=0.21070616$ is shown. The evolutionary distances were computed using the Tajima-Nei method and are in the units of the number of base substitutions per site. The analysis involved 16 nucleotide sequences. All ambiguous positions were removed for each sequence pair.

Table 4. Relative synonymous codon usage patterns among three coleopteran pests

\begin{tabular}{cccccccc}
\hline Codon & RSCU & Codon & RSCU & Codon & RSCU & Codon & RSCU \\
\hline UUU & 1.62 & UCU & 2.77 & UAU & 1.5 & UGU & 0 \\
UUC & 0.38 & UCC & 0.96 & UAC & 0.5 & UGC & 0 \\
UUA & 4.21 & UCA & 1.07 & UAA & 2 & UGA & 2 \\
UUG & 0.05 & UCG & 0 & UAG & 0 & UGG & 0 \\
CUU & 0.41 & CCU & 2.64 & CAU & 1.68 & CGU & 1.4 \\
CUC & 0 & CCC & 0.36 & CAC & 0.32 & CGC & 0 \\
CUA & 1.28 & CCA & 1 & CAA & 2 & CGA & 2.6 \\
CUG & 0.05 & CCG & 0 & CAG & 0 & CGG & 0 \\
AUU & 1.88 & ACU & 1.42 & AAU & 1.85 & AGU & 1.07 \\
AUC & 0.12 & ACC & 0.58 & AAC & 0.15 & AGC & 0.43 \\
AUA & 1.71 & ACA & 1.92 & AAA & 2 & AGA & 1.71 \\
AUG & 0.29 & ACG & 0.08 & AAG & 0 & AGG & 0 \\
GUU & 2.19 & GCU & 1.64 & GAU & 1.64 & GGU & 0.61 \\
GUC & 0.44 & GCC & 0.92 & GAC & 0.36 & GGC & 0.26 \\
GUA & 1.31 & GCA & 1.38 & GAA & 2 & GGA & 2.48 \\
GUG & 0.06 & GCG & 0.07 & GAG & 0 & GGG & 0.65 \\
\hline
\end{tabular}

steps from the common ancestors. A. lewisii showed the highest amount of mutational steps among all the coleopteran pests and genetically distant species from its common ancestors by 78 mutational numbers. 


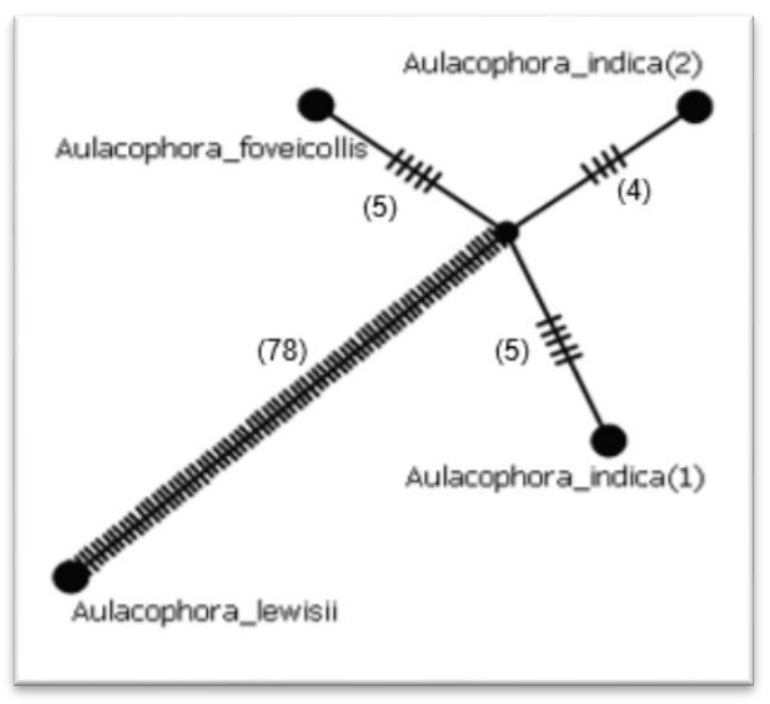

Fig. 5. Haplotype analysis was constructed by Popart 1.7 software based on TCS network. Large black circles represent the haplotype and small circles, the immediate common ancestors. Mutational steps are presented by hatch marks and numbers.

Molecular ecology research on insect pests of agricultural importance may lead to identifying new species, biotypes (Perring 2001), cryptic species (Hebert et al. 2004) and haplotypes (Toda and Murai 2007), which are difficult to study relying only on morphological characters. In this scenario, while classical taxonomy has its own strengths, molecular identification employing COI barcoding has the added advantage of not being limited by polymorphism, sexual form (asexual/sexual) and life stages of the target species (Asokan et al. 2011). COI gene sequences have turned into a vital and increasingly used tool as part of an integrative taxonomy in recent species descriptions (Hendrich and Balke 2011, Butcher et al. 2012). The present study was based on the molecular identification of three Aulacophora pests in economically important vegetable crops which were identified by COI.

The COI gene of all the specimens exhibited a high proportion of AT nucleotides, which was in agreement with previous findings made in Coleoptera and other insects (Simon et al. 1994, Daniel 1999, Bajpai and Tewari 2010, Zhuang et al. 2011, Zhang et al. 2007, Aslam et al. 2019a and 2019b, Rain et al. 2019). This was caused by A-T bond, which has a noncoding region that has faster evolution rate compared to the coding region. The AT richness increases the amount of potential transversions and led to a low proportion within the ts: tv ratio. 
Genetic distance analysis revealed that intraspecific genetic divergence ranged between 0.0158 and 0.1415 . In $96.4 \%$ of the cases, analysis of evolutionary divergence using the K2P model and the $3 \%$ cut-off criteria suggested for species level divergence (Hebert et al. 2003). DNA barcoding studies on insects and invertebrates have shown maximum intraspecific variation ranging from 3 to 3.9\% (Carew et al. 2007). Zhuang et al. (2011) performed phenogram analysis using UPGMA tree to examine the ability of the COI region to resolve the Coleopteran species identities and taxonomic relationships between species of six genera owing to every species forming its own group with very high similarity respectively. The phylogenetic relationships of the three major species groups of Coleopteran were inferred using the simultaneous analysis of $642 \mathrm{bp}$ of the most conserved part of mitochondrial DNA cytochrome oxidase I (COI) (Bernhard et al. 2009). Maximum likelihood analysis of the present study indicated that A. indica (1), A. indica (2), A. foveicollis were clustered in one group and $A$. lewisii was another group. Haplotype analysis of mitochondrial COI gene of Coleopteran pests also described that A. indica, A. lewisii and A. foveicollis are separated from their common ancestors by different number of mutational steps.

In conclusion, results indicated that the COI-based pest identification was extremely effective for insects because all the species were accurately and successfully identified based on the COI marker profile. The current study provides a useful reference backbone for research on pest based on MT-COI gene sequence through establishing DNA barcode dataset. This information might facilitate in implementation of pest management program.

\section{LITERATURE CITED}

ASLAM, A. F. M., SUlTANA, S., RAIN, F. F., SARKER, S., DAS, S. R., SIDDIKA, A. and HOWLADER, A. J. 2019a. Molecular characterization and identification of three stored grain pests based on mitochondrial cytochrome C oxidase subunit I (COI) gene sequences. Bangladesh J. Zool. 47(1): $1-11$.

ASLAM, A. F. M., SUlTANA, S., DAS, S. R. and HOWLADER, A. J. 2019b. DNA barcoding to resolve the confusion in identifying Tribolium confusum and Tribolium castaneum. Bangladesh $J$. Zool. 47(2): 333-342.

ASLAN, I., WARCHALOWSKI, A. and ÖZBEK, H. 2000. A preliminary review of the subfamily Galerucinae (Coleoptera, Chrysomelidae) in Turkey. J. Entomol. Res. Soc. 2(2): 27-42.

ASOKAN, R., REBIJITH, K. B., SINGH, S. K., SIDHU, A. S., SIDDHARTHAN, S., KARANTH, P. K. and RAMAMURTHY, V. V. 2011. Molecular identification and phylogeny of Bactrocera species (Diptera: Tephritidae). Fla. Entomol. 94: 1026-1035. 
AZIM, M.I.I. 1966. Studies on the biology of red pumpkin beetle, Aulacophora foveicollis (Lucas) (Chrysomelidae: Coleoptera) in East Pakistan. M. Sc. Thesis. Department of Entomology. Bangladesh Agricultural University, Mymensingh, 1-95.

BAJPAI, N. and TEWARI, R. R. 2010. Mitochondrial DNA sequence-based phylogenetic relationship among flesh flies of the genus Sarcophaga (Sarcophagidae: Diptera). J. Genet. 89: 51-54.

BEGUM, L.A.A. 2002. Host preference of fruit fly and red pumpkin beetle to different cucurbit vegetables grown in summer. M.S. Thesis. Department of Entomology. BSMRAU, Gazipur, Bangladesh.

BERGSTEN, J., BRILMYER, G., CRAMPTON-PLATT, A. and NILSSON1, A.N. 2012. Sympatry and color variation disguised well-differentiated sister species: Suphrodytes revised with integrative taxonomy including $5 \mathrm{kbp}$ of housekeeping genes (Coleoptera: Dytiscidae). DNA Barcodes. 1: 118.

BERNHARD, D., RIBERA, I., KOMAREK, A. and BEUTEL, R.G. 2009. Phylogenetic analysis of Hydrophiloidea (Coleoptera:Polyphaga) based on molecular data and morphological characters of adults and immature stages. Insect Syst. Evol. 40 (1):3-41.

BUTANI, D.K. and JOTWANI, M.G. 1984. Insects in vegetables. Periodical Expert Book Agency. D-42, Vivek vihar-110032, India. pp, 4-293.

BUTCHER, B. A., SMITH, M. A., SHARKEY M. J. and QUICKE, D. L. J. 2012. A turbo-taxonomic study of Thai Aleiodes (Aleiodes) and Aleiodes (Arcaleiodes) (Hymenoptera: Braconidae: Rogadinae) based largely on $\mathrm{CO} 1$ barcoded specimens, with rapid descriptions of 179 new species. Zootaxa. 3457: 1-232.

CAREW, M.E., PETTIGROVE, V., COX, R.L. and HOFFMANN, A.A. 2007. DNA identification of urban Tanytarsini chironomids (Diptera : Chironomidae). J. North Am. Benthol. Soc. 26: 587-600.

CLEMENT, M., POSADA, D. and CRANDALL, K.A. 2000. TCA: a computer program to estimate gene genealogies. Mol. Ecol. 9 (10): 1657-1659.

DANIEL, J. F. 1999. Molecular systematics of cytochrome oxidase I and 16s from Neochlamisus leaf beetle and the importance of sampling. Mol. Biol. Evol. 16 (1): 67-82.

FOLMER, O., BLACK, M., HOEH, W., LUTZ, R. and VRIJENHOEK, R. 1994. DNA primers for amplification of mitochondrial cytochrome c oxidase subunit I from diverse metazoan invertebrates. Mol. Marine Biol. Biotechnol. 13(5): 294-299.

GILlESPIE, J. J., TALLAMY, D. W., RILEY, E. G. and COGNATO, A. I. 2008. Molecular phylogeny of rootworms and related galerucine beetles (Coleoptera: Chrysomelidae). Zool. Scr. 37(2): 195222.

HASHEMI-AGHDAM, S.S., RAFIE, G., AKBARIS and OSHAGHI, M.A. 2017. Utility of mtDNA-COI barcode region for phylogenetic relationship and diagnosis of five common pest cockroaches. $J$. Arthropod Borne Dis. 11(2):182-193. 
HASSAN, M.K., UDDIN, M.M., and HAQUE, M.A. 2012. Host susceptibility of red pumpkin beetle, Aulacophora foveicollis (Lucas) among different cucurbitaceous hosts. J. Appl. Life Sci. 1 (4): 91-100.

HEBERT, P.D.N., CYWINSKA, A., BALL S.L. and DEWAARD, J.R. 2003. Biological identifications through DNA barcodes. P. Roy. Soc. B- Biol. Sci. 270(1512): 313-321.

HEBERT P.D.N., STOECKLE M.Y., ZEMLAK T.S. and FRANCIS, C.M. 2004. Identification of birds through DNA barcodes. PLoS. Biol. 2: 1657-1663.

HENDRICH, L. and BALKE, M. 2011. A simultaneous journal/wiki publication and dissemination of a new species description: Neobidessodes darwiniensis sp. n. from northern Australia (Coleoptera, Dytiscidae, Bidessini). Zoo Keys. 79: 11-20.

KAMAL, M. M., UDDIN, M.M., SHAHJAHAN, M., RAHMAN, M.M., ALAM, M.J., ISLAM, M.S., RAFI, M.Y. and LATIF, M.A. 2014. Incidence and host preference of red pumpkin beetle, Aulacophora foveicollis (Lucas) on cucurbitaceous vegetables. Life Sci.11 (7): 459-466.

KUMAR, S., STECHER, G., LI M., KNYAZ, C. and TAMURA, K. 2018. MEGA X: Molecular Evolutionary Genetics Analysis across computing platforms. Mol. Biol. Evol. 35 (6):1547-1549.

LEE, C. F. and BEENEN, R. 2015. Revision of the genus Aulacophora from Taiwan (Coleoptera: Chrysomelidae: Galerucinae). Zootaxa. 3949(2): 151-190.

MILLER, D.R. and ROSSMAN, A.Y. 1995. Systematics, biodiversity and agriculture. Bioscience. 45 : 680-686.

MUKHA, D., BRIAN, W.M. and SCHAL, C. 2001. Evolution and phylogenetic information content of the ribosomal DNA repeat unit in the Blattodea (Insecta). Insect Biochem. Mol. Biol. 32(9): 951960.

PECHAL, J. L., AUSTIN, J. W., SZALANSKI, A. L., GOLD, R. E. and TOMBERLIN, J. K. 2008. Genetic analysis of Periplaneta americana (Blattodea: Blattidae) in central Texas using the ITS1 region. J. Agric. Urban Entomol. 25(3): 179-191.

PERRING, T.M. 2001. The Bemisia tabaci species complex. Crop Prot. 20 : 725-737.

RAIN, F.F., HOWLADER, A.J. and ASLAM, A.F.M. 2019. Molecular identification and characterization of medically and veterinary important flies of Bangladesh based on mitochondrial COI gene sequences. AsPac J. Mol. Biol. Biotechnol. 27 (4): 69-79.

RASHID, M. A., KHAN, M. A., ARIF, M. J., and JAVED, N. 2014. Red Pumpkin Beetle, Aulacophora foveicollis Lucas; A Review of host susceptibility and management practices. J. Entomol. 7(1): 38-54.

REETA, R. and JOHRI, P. K. 2003. Seasonal biology, abundance and intensity of attack of red pumpkin beetle, Aulacophora foveicollis (Lucas) on cucurbit crops at Kanpur in Uttar Pradesh. J. Appl. Zool. Res. 14(2): 144-147.

SIMON, C., FRATI, F., BECKENBACH, A., CRESPI, B., LIU, H. and LOOK, P. F. 1994. Evolution, weighting and phylogenetic utility of mitochondrial gene sequences and a compilation of conserved polymerase chain reaction primers. Ann. Entomol. Soc. Am. 87 (6): 651-701. 
TODA, S. and MURAI, T. 2007. Phylogenetic analysis based on mitochondrial COI gene sequences in Thrips tabaci Lindeman (Thysanoptera: Thripidae) in relation to reproductive forms and geographic distribution. Appl. Entomol. Zool. 42: 309-316.

UDDIN, M.J. 1996. Development of suitable package(s) of IPM components for the management of selected insect pests of cucumber. MS Thesis, Department of Entomology, Institute of Post Graduate Studies in Agriculture, Gazipur, Bangladesh. p. 72.

WALLMAN, J.F. and DONNELLAN, S.C. 2001. The utility of mitochondrial DNA sequences for the identification of forensically important blowflies (Diptera: Calliphoridae) in southeastern Australia. Forensic Sci. Int.120 (1-2): 60-67.

YANG, Z.H. and RANNALA, B. 2010. Bayesian species delimitation using multilous sequence data. Proc. Natl. Acad. Sci.107: 9264-9269.

ZHANG, M., CAO, T., ZHANG, R., GUO, Y., DUAN, Y. and MA, E. 2007. Phylogeny of Apaturinae butterflies (Lepidoptera: Nymphalidae) based on mitochondrial cytochrome oxidase I gene. J. Genet. Genomics. 34: 812- 823.

ZHUANG, Q., CAI, J., ZHANG, M., FENG, H., GUO, Y., LAN, L., and CHEN, Y. 2011. Molecular identification of forensically significant beetles (Coleoptera) in China based on COI gene. Rev. Colomb. Entomol. 37(1): 95-102.

(Manuscript received on 14 February, 2020 revised on 17 August, 2020) 